\title{
TINGKAT KETERGANTUNGAN ACTIVITY DAILY LIVING (ADL) PADA PASIEN STROKE (ISKEMIK DAN HEMORAGIK) BERDASARKAN INDEKS BARTHEL DI RSUD DR. HARJONO S. PONOROGO
}

\author{
Saiful Nurhidayat ${ }^{1}$, Sulistyo Andarmoyo ${ }^{2}$, Wiwik Widiyati ${ }^{3}$ \\ ${ }_{1,2,3}$ Prodi S1 Keperawatan Universitas Muhammadiyah Ponorogo \\ E-mail: saiful.nurhidayat2@gmail.com
}

\begin{abstract}
Dependence caused by stroke varies which can be manifested in daily activities (Activity Daily Living / $A D L$ ). The Barthel index is a measuring tool used to measure the level of independence of basic daily activities. ADL measurement with the Barthel Index helps early identify the level of client independence in fulfilling ADL. Type of research is a non experimental research, this research is a comparative observational analytic study with a cross sectional approach. The purpose of this study was to determine the level of $A D L$ dependence in stroke patients based on the barthel index carried out in the inpatient room for stroke patients at Dr. Harjono S Ponorogo Hospital, with a sample of 30 respondents according to the inclusion criteria and taken by consecutive sampliang. Sampling was analyzed using the independent sample $t$ test statistical test if the two samples were normally distributed but the data of one sample or both were not normally distributed, then the hypothesis test used the Mann Whitney test. Instrument of data collection using questionnaires and observation sheets with the results of the study of 30 respondents consisting of 16 patients with ischemic stroke and 16 patients with bleeding stroke. Activity Daily Living ( $A D L)$ assessments in ischemic stroke patients are mostly totally dependent, almost all of them are totally dependent. The results of the Mann Whitney U Test, the sig value (2 tailed) is 0.440 , so this value is $>0.05$, with the conclusion that there is no difference in the level of dependence on daily living activity in patients with ischemic stroke and hemorrhagic stroke based on the Barthel index.
\end{abstract}

Keywords : Stroke Hemoragic, Stroke Iskemic, ADL, Barthel Indeks

\begin{abstract}
Abstrak : Ketergantungan yang ditimbulkan akibat stroke bervariasi yang dapat dimanifestasikan dalam aktivitas sehari-hari (Activity Daily Living/ADL). Indeks Barthel merupakan salah satu alat ukur yang digunakan untuk mengukur tingkat kemandirian aktivitas dasar sehari hari. Pengukuran ADL dengan Indeks Barthel membantu mengidentifikasi dini tingkat kemandirian klien dalam pemenuhan ADL nya. Jenis penelitian ini adalah penelitian non eksperimental, penelitian ini merupakan penelitian analitik komparatif observasional dengan pendekatan cross sectional. Tujuan Penelitian ini untuk mengetahui tingkat ketergantungan ADL pada pasien stroke iskemik dan hemoragik berdasarkan indeks bartel yang dilakukan di Ruang Rawat Inap Pasien Stroke RSUD Dr Harjono S Ponorogo, dengan sampel sejumlah 30 responden sesuai dengan kriteria inklusi dan diambil secara Consecutive Sampling. Sampling dianalisis menggunakan uji statistik independent sample t test jika kedua sampel berdistribusi normal, tetapi data salah satu sampel atau keduanya tidak berdistribusi normal, maka uji hipotesis menggunakan Uji Mann Whitney. Instrumen untuk pengumpulan data menggunakan kuesioner dan lembar observasi dengan hasil penelitian dari 30 responden terdiri dari 16 pasien stroke iskemik dan 16 pasien stroke hemoragik. Penilaian ADL pada pasien stroke iskemik sebagian besar mengalami ketergantungan total, pasien stroke hemoragik hampir seluruhnya mengalami ketergantungan total. Hasil uji Mann Whitney $U$ Test, nilai sig (2 tailed) adalah 0,440 maka nilai ini > 0,05, dengan kesimpulan bahwa tidak ada perbedaan tingkat ketergantungan Activity Daily Living pada pasien stroke iskemik dan stroke hemoragik berdasarkan indeks barthel.
\end{abstract}

Kata Kunci : Stroke Hemoragik, Stroke Iskemik, ADL, Indeks Barthel

\section{PENDAHULUAN}

Stroke adalah manifestasi klinis dari gangguan fungsi otak, baik fokal maupun global (menyeluruh), yang terjadi mendadak, berlangsung lebih dari 24 jam atau sampai menyebabkan kematian, tanpa penyebab lain selain gangguan vaskuler. Stroke dapat diklasifikasikan sebagai hemoragik atau iskemik. Stroke iskemik mengacu pada penyumbatan aliran darah otak karena bekuan darah, yang baik karena trombosis atau karena emboli dan lebih umum terjadi dari pada stroke hemoragik (WHO, 2010). Stroke hemoragik menyumbang $10-15 \%$ dari semua stroke dan berhubungan dengan tingkat kematian yang lebih tinggi dari pada stroke iskemik. Khan dkk, melakukan penelitian terhadap 280 pasien stroke di Rumah Sakit Ziauddin 
Karachi mengamati $(70,1 \%)$ mengalami stroke iskemik dan (29\%) mengalami stroke Hemoragik. Sedangkan di Indonesia, stroke merupakan penyebab kematian sebesar $12,1 \%$ - $88 \%$ dari seluruh kejadian stroke diakibatkan oleh stroke iskemik atau non hemoragik.

Berdasarkan Riset Kesehatan Dasar (Riskesdas) Nasional tahun 2013, prevalensi stroke di Indonesia berdasarkan diagnosis tenaga kesehatan sebesar tujuh per mil dan terjadi peningkatan pada hasil Riskesdas tahun 2018 yaitu menjadi 10,9 dan yang terdiagnosis oleh tenaga kesehatan (NaKes) atau gejala sebesar 12,1 per mil. Jadi, sebanyak 57,9 \% penyakit stroke telah terdiagnosis oleh NaKes. Prevalensi stroke berdasarkan diagnosis NaKes tertinggi di Sulawesi Utara (10,8\%), diikuti DI Yogyakarta (10,3\%), Bangka Belitung dan DKI Jakarta masingmasing 9,7 per mil sedangkan Sumatera Barat 7,4 per mil. Prevalensi stroke berdasarkan diagnosis NaKes dan gejala tertinggi terdapat di Sulawesi Selatan $(17,9 \%)$, DI Yogyakarta (16,9\%), Sulawesi Tengah (16,6\%), diikuti Jawa Timur sebesar $16 \%$ sedangkan Sulawesi Barat sebesar $15,5 \%$. Angka kejadian penyakit Stroke di RSUD Dr. Harjono S Ponorogo bulan Januari-Desember 2017 sebesar 895 dan merupakan penyakit kedua terbesar dalam 10 besar penyakit di RSUD Dr. Harjono S Ponorogo.

Stroke merupakan penyebab utama gangguan fungsional, dimana $20 \%$ penderita yang bertahan hidup masih membutuhkan perawatan di institusi kesehatan setelah 3 bulan dan 15-30\% penderitanya mengalami cacat permanen (Yenni, 2011). Tingginya angka kejadian stroke dan dampak dari gejala sisa yang ditimbulkan oleh stroke patut diperhatikan, ketergantungan yang ditimbulkan akibat stroke sangatlah bervariasi yang dapat dimanifestasikan oleh pasien lewat kemampuan dalam melakukan aktivitas

\section{METODE PENELITIAN}

Penelitian ini merupakan penelitian analitik komparatif observasional dengan pendekatan waktu yang digunakan adalah cross sectional. Jenis penelitian ini adalah penelitian non eksperimental. Penelitian dilaksanakan di ruang rawat inap pasien sehari-hari (Activity Daily Living / ADL). Khasanah (2012), menyatakan outcome stroke pada umumnya digambarkan dalam bentuk angka kematian dan status fungsional setelah serangan stroke. Penurunan kemampuan dapat terjadi dikarenakan penurunan kesadaran serta daerah otak tertentu tidak berfungsi yang disebabkan terganggunya aliran darah ditempat tersebut atau pecahnya pembuluh darah pada tempat tersebut. Keadaan paska stroke dalam perjalanannya sangat beragam, bisa pulih sempurna atau sembuh dengan cacat ringan, sedang dan berat. Banyak penderita stroke yang menjadi cacat sehingga tidak mampu mencari nafkah seperti sebelum sakit, menjadi tergantung pada orang lain dan tidak jarang menjadi beban keluarganya.

Perawatan ditujukan untuk mengurangi dampak kecacatan dan meningkatkan kemampuan penyandang cacat untuk mengatasi masalah disabilitas dengan suatu rangkaian proses terapi atas kerjasama tenaga kesehatan profesional di ruang perawatan yang tersedia dan keluarga guna meringankan gangguan kognitif yang dialami serta meningkatkan kemampuan hidup sehari-hari sampai interaksi sosial (Departemen Kesehatan RI, 2013)

Activity Daily Living pada klien paska stroke dilihat dari kemandirian penderita Stroke dalam melakukan aktivitas seharihari. Indeks Barthel merupakan salah satu alat ukur yang dapat digunakan untuk mengukur tingkat kemandirian terhadap aktivitas dasar sehari hari. Pengukuran ADL dengan Indeks Barthel akan membantu perawat dalam melakukan pengkajian dan identifikasi dini tingkat kemandirian klien dalam pemenuhan ADL nya. Berdasarkan tersebut atas, maka peneliti tertarik ingin mengetahui Tingkat Ketergantungan Activity Daily Living Pada Pasien Stroke Iskemik Dan Stroke Hemoragik Berdasarkan Indeks Barthel di RSUD Dr.Harjono S Ponorogo.

stroke. Berdasarkan waktu penelitian adalah potong lintang (cross sectional) yaitu penelitian yang digunakan untuk mempelajari dinamika hubungan antar variabel bebas (faktor resiko / eksposure) dengan variabel tergantung (efek) yang 
pengukurannya dilakukan hanya satu kali pada satu saat (tidak ada follow-up) (Murti Bhisma, 2003). Variabel penelitian ini adalah tingkat ketergantungan ADL pada pasien stroke iskemik dan hemoragi berdasarkan indeks barthel. Lokasi penelitian ini dilakukan di Ruang Rawat Inap Pasien Stroke RSUD Dr. Harjono S Ponorogo. Populasi penelitian ini adalah seluruh pasien yang mengalami gejala stroke yang dirawat di ruang rawat inap stroke di RSUD Dr.Harjono S Ponorogo dengan tehnik pengambilan sampel adalah consequtive sampling.

Sampel dari penelitian ini diambil sesuai dengan kriteria inklusi yang digunakan dalam penelitian ini adalah semua pasien stroke yang mau berpartisipasi, pasien stroke pria dan wanita, pasien yang didiagnosa stroke hemoragik dan stroke iskemik di ruang rawat inap stroke di RSUD Dr.Harjono S Ponorogo

Besar sampel yang digunakan adalah 30 pasien untuk 2 kelompok (stroke iskemik dan stroke hemoragi). Instrumen penelitian menggunakan kuesioner dan lembar observasi.

Uji hipotesis yang digunakan dalam pengujian ini adalah independent sample ttest, untuk mengetahui apakah terdapat perbedaan antara dua kelompok sampel yang diteliti. Jika data salah satu sampel atau keduanya tidak berdistribusi normal, maka uji hipotesis perbadingan dilakukan dengan menggunakan metode statistik non parametrik menggunakan uji Mann Whitney. Data akan diolah dengan Statistical Product and Service Solution (SPSS version 24 for windows dengan taraf signifikansi $5 \%$.

\section{HASIL PENELITIAN}

Tabel 1 Distribusi Frekuensi Responden Berdasarkan Karakteristik Umum

\begin{tabular}{|c|c|c|c|c|c|}
\hline \multicolumn{2}{|c|}{ Data Umum } & \multicolumn{2}{|c|}{ Iskemik } & \multicolumn{2}{|c|}{ Hemoragik } \\
\hline & काषй & $\mathbf{n}$ & $\%$ & $\mathbf{n}$ & $\%$ \\
\hline Jenis kelamin & $\begin{array}{l}\text { Laki - Laki } \\
\text { Perempuan }\end{array}$ & $\begin{array}{c}10 \\
6\end{array}$ & $\begin{array}{l}63 \\
37\end{array}$ & $\begin{array}{c}10 \\
4\end{array}$ & $\begin{array}{l}71 \\
29\end{array}$ \\
\hline Umur & $\begin{array}{c}41-50 \text { Tahun } \\
51-60 \text { Tahun } \\
61-70 \text { Tahun } \\
>71 \text { Tahun }\end{array}$ & $\begin{array}{l}1 \\
7 \\
6 \\
2\end{array}$ & $\begin{array}{c}6 \\
44 \\
38 \\
13\end{array}$ & $\begin{array}{l}0 \\
3 \\
9 \\
2\end{array}$ & $\begin{array}{c}0 \\
21 \\
64 \\
15\end{array}$ \\
\hline Pendidikan & $\begin{array}{c}\text { Tidak Sekolah } \\
\text { SD } \\
\text { SMP } \\
\text { SMA } \\
\text { PT }\end{array}$ & $\begin{array}{c}1 \\
10 \\
1 \\
3 \\
1\end{array}$ & $\begin{array}{c}6 \\
63 \\
6 \\
19 \\
6\end{array}$ & $\begin{array}{l}1 \\
8 \\
0 \\
5 \\
0\end{array}$ & $\begin{array}{c}7 \\
57 \\
0 \\
36 \\
0\end{array}$ \\
\hline Pekerjaan & $\begin{array}{c}\text { Tidak bekerja } \\
\text { IRT } \\
\text { Tani } \\
\text { Wiraswasta/Pedagang } \\
\text { Pegawai Swasta } \\
\text { PNS/ABRI/POLRI/Purn }\end{array}$ & $\begin{array}{l}0 \\
2 \\
6 \\
3 \\
3 \\
2\end{array}$ & $\begin{array}{c}0 \\
13 \\
38 \\
19 \\
19 \\
13\end{array}$ & $\begin{array}{l}0 \\
1 \\
6 \\
3 \\
2 \\
2\end{array}$ & $\begin{array}{c}0 \\
7 \\
43 \\
21 \\
14 \\
14\end{array}$ \\
\hline Total & & 49 & 100 & 14 & 100 \\
\hline
\end{tabular}

Tabel 1 di atas menunjukkan bahwa menurut jenis kelamin bahwa sebagian besar berjenis kelamin laki - laki untuk kejadian stroke Hemoragik stroke iskemik masing - masing 10 orang, sebagian besar pada stroke Hemoragik berusia $51-60$ tahun yaitu 7 orang dan pada stroke iskemik berusia 61 - 70 tahun yaitu 9 orang, sebagian besar pendidikan adalah SD pada stroke Hemoragik 10 orang dan pada stroke iskemik 8 orang, dan berdasarkan pekerjaan sebagian besar sebagai petani stroke Hemoragik stroke iskemik masing - masing yaitu 6 orang. 
Tabel 2 Distribusi subyek penelitian berdasarkan Data Khusus

\begin{tabular}{clcccc}
\hline & \multirow{2}{*}{ Data Khusus } & \multicolumn{2}{c}{ Iskemik } & \multicolumn{2}{c}{ Hemoragik } \\
\cline { 3 - 6 } & & $\mathbf{n}$ & $\mathbf{\%}$ & $\mathbf{n}$ & $\%$ \\
\hline Kesadaran & Compos Mentis & 10 & 63 & 7 & 50 \\
& Apatis & 0 & 0 & 1 & 7 \\
& Somnolen & 3 & 19 & 1 & 7 \\
& Stupor & 2 & 13 & 3 & 21 \\
& Koma & 1 & 5 & 2 & 14 \\
\hline \multirow{2}{*}{ Defisit Neurologis } & Lapang Pandang & 0 & 0 & 0 & 0 \\
& Motorik & 14 & 78 & 15 & 56 \\
& Sensorik & 2 & 11 & 0 & 0 \\
& Verbal & 0 & 0 & 7 & 26 \\
& Kognitif & 2 & 11 & 5 & 19 \\
& Emosional & 0 & 0 & 0 & 0 \\
\hline Total & & $\mathbf{4 9}$ & $\mathbf{1 0 0}$ & $\mathbf{1 4}$ & $\mathbf{1 0 0}$ \\
\hline
\end{tabular}

Berdasarkan tabel 2 diketahui bahwa sebagian besar responden memiliki kesadaran Compos Mentis pada stroke iskemik yaitu 10 orang dan stroke hemoragik yaitu 7 orang, sedangkan sebagian besar responden mengalami defisit neurologis motorik yaitu 14 orang.

Tabel 3 Hasil Penelitian ADL dengan Modifikasi Indeks Barthel

\begin{tabular}{|c|c|c|c|c|c|}
\hline \multirow{2}{*}{\multicolumn{2}{|c|}{ Keterangan }} & \multicolumn{2}{|c|}{ Iskemik } & \multicolumn{2}{|c|}{ Hemoragik } \\
\hline & & $\mathbf{n}$ & $\%$ & $\mathbf{n}$ & $\%$ \\
\hline Mengendalikan BAB & $\begin{array}{l}\text { a. Tak terkendali/tidak } \\
\text { teratur (Perlu Pencahar) } \\
\text { b. Kadang - kadang tidak } \\
\text { terkendali (hanya } \\
\text { 1x/minggu } \\
\text { c. Terkendali Teratur }\end{array}$ & 8 & $\begin{array}{l}31 \\
50\end{array}$ & 9 & 64 \\
\hline $\begin{array}{l}\text { Mengendalikan } \\
\text { Rangsang BAK }\end{array}$ & $\begin{array}{l}\text { a. Tidak terkendali/pakai } \\
\text { kateter } \\
\text { b. Kadang - kadang tidak } \\
\text { terkendali (hanya 1x/24 } \\
\text { jam) } \\
\text { c. Mandiri }\end{array}$ & $\begin{array}{l}6 \\
6\end{array}$ & $\begin{array}{l}37,5 \\
37,5\end{array}$ & $\begin{array}{l}7 \\
6\end{array}$ & 50 \\
\hline $\begin{array}{l}\text { Penggunaan WC, } \\
\text { melepas I memakai } \\
\text { celana, menyiram }\end{array}$ & $\begin{array}{l}\text { a. Tergantung pertolongan } \\
\text { orang lain } \\
\text { b. Perlu pertolongan pada } \\
\text { beberapa kegiatan tetapi } \\
\text { dapat mengerjakan } \\
\text { sendiri beberapa kegiatan } \\
\text { yang lain } \\
\text { c. Mandiri }\end{array}$ & $\begin{array}{l}9 \\
5\end{array}$ & $\begin{array}{l}56 \\
31\end{array}$ & $\begin{array}{l}11 \\
2\end{array}$ & 14 \\
\hline $\begin{array}{l}\text { Makan minum } \text { (Jika } \\
\text { makan harus berupa } \\
\text { potongan, } \\
\text { dibantu dianggap }\end{array}$ & $\begin{array}{l}\text { a. Dibantu } \\
\text { b. Perlu ditolong memotong } \\
\text { makanan } \\
\text { c. Mandiri }\end{array}$ & $\begin{array}{c}4 \\
11 \\
1\end{array}$ & $\begin{array}{l}25 \\
69 \\
6\end{array}$ & $\begin{array}{c}10 \\
3 \\
1\end{array}$ & $\begin{array}{l}71 \\
21\end{array}$ \\
\hline
\end{tabular}




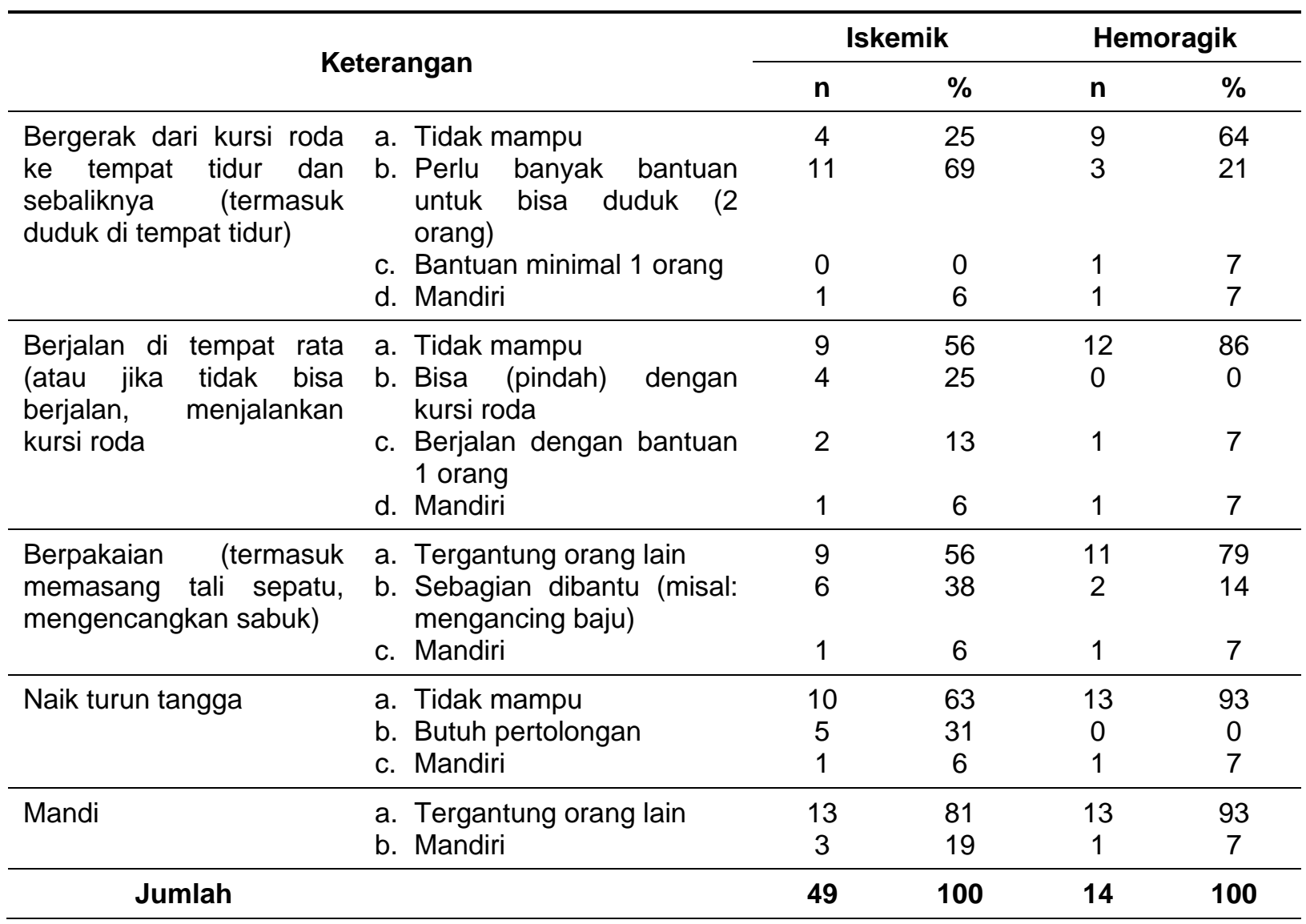

Pada tabel 3 di atas menunjukkan hasil penilaian ADL berdasarkan indeks Barthel, pada pasien stroke hemoragi lebih besar jumlah responden yang mengalami ketergantungan total dibandingkan dengan stroke iskemik, seperti dalam hal mengendalikan $B A B$, rangsangan $B A K$, mandi, dan naik turun tangga.

Tabel 4 Penilaian Activity Daily Living (ADL) pada Pasien Stroke Iskemik dan Stroke Hemoragik

\begin{tabular}{cccccc}
\hline \multirow{2}{*}{ Nilai Barthel } & \multicolumn{2}{c}{ Iskemik } & \multicolumn{2}{c}{ Hemoragik } & \multirow{2}{*}{ Kategori } \\
\cline { 2 - 5 } & $\mathbf{n}$ & $\%$ & $\mathbf{n}$ & $\%$ & \\
\hline $0-4$ & 10 & 63 & 11 & 79 & Ketergantungan Total \\
$5-8$ & 0 & 0 & 0 & 0 & Ketergantungan Berat \\
$9-11$ & 4 & 25 & 1 & 7 & Ketergantungan Sedang \\
$12-19$ & 1 & 6 & 1 & 7 & Ketergantungan Ringan \\
20 & 1 & 6 & 1 & 7 & Ketergantungan Mandiri \\
\hline
\end{tabular}

Tabel 4 di atas menunjukkan Penilaian Activity Daily Living (ADL) padapasien stroke iskemik sebagian besar mengalami ketergantungan total, sedangkan pada pasien stroke Hemoragik hamper seluruhnyamengalami ketergantungan total juga.

Tabel 5 Tabel Uji Mann-Whitney Activity Daily Living (ADL) pada Pasien Stroke Iskemik dan Stroke Hemoragik

\begin{tabular}{ccccc}
\hline & Diagnosa & N & Mean Rank & $\begin{array}{c}\text { Sum Of } \\
\text { Rank }\end{array}$ \\
\hline $\begin{array}{c}\text { Skor } \\
\text { Barthel }\end{array}$ & Iskemik & 16 & 14,56 & 233,00 \\
\hline
\end{tabular}




\section{Skor Barthel}

$\begin{array}{lc}\text { Mann-Whitney U } & 97,000 \\ \text { Wilcoxon W } & 233,000 \\ \text { Z } & -, 772 \\ \text { Asymp. Sig. (2-tailed) } & , 440 \\ \text { Exact Sig. [2*(1-tailed Sig.)] } & , 552 \mathrm{~b}\end{array}$

Data yang diperoleh dari hasil penelitian diolah dalam program Statistical Product and Service Solution (SPSS) version 24 for Windows. Analisis data menggunakan independent sample t Test. Syarat dilakukan uji independent sample $t$ Test adalah memiliki sebaran data yang normal. Berdasarkan tabel output tests of normality didapatkan data bahwa nilai tersebut $<0,05$ maka dapat disimpulkan bahwa data berdistribusi tidak normal. Sehingga akan dilakukan uji Mann Whitney U Test atau disebut juga dengan Wilcoxon Rank Sum Test. Jika probabilitas > 0,05 maka Ho diterima dan Ha ditolak berarti tidak terdapat perbedaan yang signifikan antara Tingkat Ketergantungan Activity Daily Living Pada Pasien Stroke Iskemik Dan Stroke Hemoragik. Interpretasi uji Mann Whitney $U$ Test pada penelitian ini adalah Nilai sig (2 tailed) adalah 0,440 maka nilai ini > 0,05, dengan kesimpulan bahwa tidak ada perbedaan ADL pada pasien stroke Iskemik dan Hemoragik.

\section{PEMBAHASAN}

Sampel dalam penelitian ini sebanyak 30 orang yang terdiri dari 20 orang laki laki $(67 \%)$ dan 10 orang perempuan (33\%) dengan 16 orang menderita stroke iskemik (53\%) dan 14 orang stroke Hemoragik (14\%). Data sampel diperoleh dari hasil anamnesa, pemeriksaan fisik pasien dan pemeriksaan CT scan kepala pada saat terkena serangan stroke akut.

Pada tabel 4 didapatkan hasil penilaian mayoritas pasien perlu bantuan penuh karena pasien mengalami ketergantungan total dengan nilai indeks Barthel ada pada rentang nilai 0-4 sejumlah 10 orang (63\%) stroke iskemik dan 11 orang $(79 \%)$ pasien stroke Hemoragik. Pada pasien tersebut di atas mayoritas tidak bisa melakukan kegiatan seperti membersihkan diri, menggunakan sarana toileting, bergerak dari kursi roda, berjalan di tempat yang rata, berpakaian, naik turun tangga dan juga mandi. Kegiatan-kegiatan ini harus dibantu dan dipenuhi oleh orang lain.

Activity Daily Living mencakup ketrampilan dasar yang harus dimiliki seseorang untuk merawat diri secara mandiri yang dikerjakan seseorang seharihari dengan tujuan memenuhi atau berhubungan dengan perannya sebagai pribadi dalam keluarga dan masyarakat (Prakoso, K., Vitriana, V., \& Ong, 2016).

Bermawi, et al., (2000) mengatakan bahwa sekitar 30-60 \% penderita stroke yang bertahan hidup menjadi tergantung dalam beberapa aspek aktivitas hidup sehari-hari.

Dari berbagai penelitian, perbaikan fungsi neurologik dan fungsi aktivitas hidup sehari-hari paska stroke menurut waktu cukup bervariasi. Suatu penelitian mendapatkan perbaikan fungsi paling cepat pada minggu pertama dan menurun pada minggu ketiga sampai 6 bulan paska stroke. Prognosis stroke juga dipengaruhi oleh berbagai faktor dan keadaan yang terjadi pada penderita stroke. Hasil akhir yang dipakai sebagai tolok ukur diantaranya outcome fungsional, seperti kelemahan motorik, disabilitas, quality of life, serta mortalitas.

Penelitian Rachmawati (2013), Fandri (2014), dan Marjoko (2012) bahwa pasien stroke dengan tingkat ketergantungan total merupakan kelompok pasien dengan jumlah paling banyak pada saat masuk rumah sakit. Pinzon (2010) dan Lingga (2013) menjelaskan bahwa pasien stroke hemoragik dan iskemik mempunyai tingkat ketergantungan total karena pasien sedang memasuki masa - masa kritis dalam 48 - 72 jam pertama, salah satunya 
ditandai dengan adanya penurunan kesadaran dan kelumpuhan motorik yang merupakan dampak terbesar dari penyakit stroke. Dalam penelitian ini, tingkat ketergantungan ADL pasien stroke, pasien stroke hemoragik maupun iskemik yang sebelumnya berada pada tingkat ketergantungan total, mengalami peningkatan skor ADL sehingga menurunkan tingkat ketergantungan ADL. Selaras dengan penelitian Fandri (2013) dan Rachmawati (2013) bahwa pasien stroke yang berada pada tingkat ketergantungan total dan parah masih menjadi kelompok pasien dengan jumlah terbanyak saat keluar rumah sakit dan tidak mengalami peningkatan yang signifikan.

Tingkat ketergantungan Activity Daily Living baik pada pasien stroke hemoragik maupun strok iskemik saat masuk rumah sakit sebagian besar berada pada tingkat ketergantungan total. Pasien stroke hemoragik maupun iskemik memasuki masa - masa kritis dalam perburukan kondisi strok saat 48-72 jam pertama sehingga kondisi klinis stroke baik stroke iskemik maupun hemoragik paling buruk berada pada hari-hari pertama paska serangan stroke. Hal tersebut ditandai dengan penurunan kesadaran dan kelumpuhan motorik yang merupakan dampak terbesar penyakit stroke (McCormack J, 2013). Penelitian yang dilakukan oleh Carlo (2018) mendapatkan hasil yang serupa dengan penelitian ini, yakni pasien stroke dengan tingkat ketergantungan total merupakan kelompok hemoragik menjalani rawat inap lebih panjang dari pada stroke iskemik. Stroke jenis hemoragik merupakan stroke dengan perburukan kondisi klinis yang lebih tinggi dibanding dengan stroke iskemik.

Stroke merupakan penyakit yang memerlukan perawatan jangka panjang, sehingga untuk mendapatkan therapeutic outcome yang baik perlu kerjasama antara dokter, perawat, apoteker, pasien dan keluarga pasien. (Junaidi, 2006). Stroke menyebabkan berbagai defisit neurologik, bergantung pada lokasi lesi (pembuluh darah mana yang tersumbat), ukuran area yang perfusinya tidak adekuat, dan jumlah aliran darah kolateral (sekunder atau aksesori). Fungsi otak yang rusak tidak dapat membaik sepenuhnya. Manifestasi klinis stroke menurut Smeltzer \& Bare
(2002), antara lain: defisit lapang pandang, defisit motorik, defisit sensorik, defisit verbal, defisit kognitif dan defisit emosional. Gangguan akibat stroke sering menimbulkan gejala sisa yang dapat menjadi kecatatan menetap dan selanjutnya membatasi fungsi seseorang dalam aktivitas kehidupan sehari hari.

Penderita stroke akan mengalami gangguan dalam melakukan Activity Daily Living (ADL) / aktivitas kehidupan sehari hari (AKS), oleh karena itu diperlukan program rehabilitasi atau pemulihan dengan tujuan utama dapat mencapai kemandirian dalam Activity Daily Living (ADL). Sel-sel otak tidak bisa langsung beregenerasi tetapi dapat membuat koneksi baru satu sama lain sehingga sel-sel saraf di otak dapat berkembang dan kembali kepada fungsi semula yang disebut dengan neuroplastisiti (Rudd, 2010).

Pasien stroke cenderung mengalami ketergantungan terhadap orang lain dalam Activity Daily Living (ADL) akibat adanya gejala sisa yang ditinggalkan oleh stroke. Gejala sisa ini terjadi akibat berbagai defisit neurologik yang disebabkan oleh adanya gangguan pembuluh darah pada otak, dimana gejala sisa yang berkepanjangan dapat mengakibatkan kecacatan pada pasien sehingga pasien tidak mampu melakukan Activity Daily Living (ADL) secara mandiri. Pemulihan neurologis terjadi di awal setelah terjadinya stroke dan kemampuan fungsional pulih sejalan dengan pemulihan neurologis yang terjadi, terutama dalam tiga sampai enam bulan pertama paska terserang stroke. (Wirawan.RP, 2009).

Pada saat keluar rumah sakit, pasien stroke hemoragik dan iskemik yang sebelumnya berada pada tingkat ketergantungan total mengalami peningkatan menjadi tingkat ketergantungan parah. Meskipun terjadi penurunan tingkat ketergantungan Activity Daily Living (ADL), tetapi penurunan yang terjadi tidak terlalu signifikan. Data tersebut selaras dengan penelitian sebelumnya yang menyatakan bahwa pasien stroke yang berada pada tingkat ketergantungan total dan parah masih menjadi kelompok pasien dengan jumlah terbanyak saat keluar rumah sakit dan tidak mengalami peningkatan yang signifikan (Carlo, 2018). 
Selain hal tersebut di atas, juga ada pengaruh kebudayaan pasien dalam hal kemandirian sangat kental bahwa keluarga beranggapan bahwa dalam keadaan sakit maka semua aktifitas sehari-hari harus dibantu secara maksimal dan pantangan untuk melakukan aktifitas, hal ini dimungkinkan dapat menjadi kendala dalam pelaksanaan Activity Daily Living, Data pendukung yang lain adalah pendidikan. Pendidikan mayoritas responden dalam penelitian ini adalah pendidikan dasar yaitu SD dan SMP sebesar $70 \%$ sehingga

\section{KESIMPULAN DAN SARAN}

Penilaian Activity Daily Living (ADL) pada pasien stroke iskemik sebagian besar mengalami ketergantungan total, sedangkan pada pasien stroke Hemoragik hampir seluruhnya juga mengalami ketergantungan total. Melihat hasil penelitian ini maka perlu dilakukan penelitian lanjutan dengan menggunakan metode longitudinal, yaitu dengan

\section{DAFTAR PUSTAKA}

Bermawi M., Meliala L., Asmedi A. 2000. Nilai Prognostik Tekanan Darah Waktu Masuk Rumah Sakit pada Penderita Stroke Infark Akut. Berkala Neuro Sains Vol. 1 No.3. FK UGM. Yogyakarta

Carlo A Di, Lamassa M, Franceschini M, Bovis F, Cecconi L, Pournajaf S, dkk. Impact of acute-phase complications and interventions on 6month survival after stroke. A prospective observational study. PLoS One. 2018;13(3):1-16.

Departemen Kesehatan Republik Indonesia. Laporan Hasil Riset Kesehatan Dasar Indonesia (Riskesdas). 2013

Fandri, Sherly., Utomo, Wasisto., \& Dewi, Ari P. (2014). Perbedaan Status Fungsional Pasien Stroke saan Masuk dan Keluar Ruang Rawat Inap RSUD Arifin Achmad.JOM PSIK Vol. 1 No.2 Oktober 2014. Diakses 30 Mei 2020 dari

http://jom.unri.ac.id/index.php/JOMPSI K/article/download/3412/3308

Junaidi I. 2003. Panduan Praktis Pencegahan Dan Pengobatan Stroke. pemahaman yang sangat kurang terutama tentang penyakit dan penatalaksanaan yang sedang dialaminya.

Hal inilah salah satu faktor yang mendukung tingginya tingkat ketergantungan pasien baik pasien stroke iskemik ataupun Hemoragik. Sehingga saat dilakukan uji Mann Whitney $U$ Test atau disebut juga dengan Wilcoxon Rank Sum Test, Nilai sig (2 tailed) adalah 0,440 maka nilai ini $>0,05$, dengan kesimpulan bahwa tidak ada perbedaan ADL pada pasien stroke iskemik dan stroke Hemoragik.

menambahkan beberapa variabel yang belum diambil dalam penelitian ini dengan jumlah sampel yang lebih banyak. Implikasi bagi keperawatan adalah dengan memberikan edukasi ROM baik kepada pasien stroke ataupun keluarga yang mendampingi untuk meningkatkan perbaikan Activity Daily Living dan kemandirian pasien stroke yang lebih baik.

Jakarta: Bhuana Ilmu Populer, KelompokGramedia.

Kemenkes RI. 2013. Riset Kesehatan Dasar; RISKESDAS. Jakarta: BalitbangKemenkes RI

Khan $\mathrm{J}$ and Rehman A. Comparison of clinical diagnosis with computed tomography in ascertaining type of stroke. J Ayub Medical Abbottabad 2005;17(3): 65-7.

Khasanah N. 2012. Lokasi Infark Berdasarkan Vaskularisasi Sebagai Faktor Prognosis Outcame Fungsional Stroke Infark Diperoleh dari: https://repository.ugm.ac.id/id/eprint 199956

Lingga, Lanny. 2013. All About Stroke. Jakarta: PT. Elex Media Komputindo

Marjoko, Bibing R., Utomo, Wasisto., \& Hasanah, Oswati. (2012) Analisis Status Fungsional Pasien Stroke Saat Keluar Ruang Merak II RSUD Arifin Achmad Pekanbaru. E Journal Universitas Riau. Diakses 27 Mei 2020 dari http://repository.unri.ac.id/xmlui/bits 
tream/handle/123456789/4826/Jurn al\%20Bibing\%20Rahmano\%20M., \%20S. Kep.pdf?sequen ce $=1$

McCormack J, Reay $H$. Acute strok research: challenges and opportunities for nurses. Nurs Stand. 2013;27(32):39-45.

Murthi, Bhisma, 2003. Prinsip dan Metode Riset Epidemiology, gajah mada University Press, Jakarta

Pinzon, Rizaldy. 2010. AWAS STROKE! Pengertian, Gejala, Tindakan, Perawatan, dan Pencegahan. Yogyakarta: PenerbitANDI.

Prakoso, K., Vitriana, V., \& Ong, A. (2016). Correlation between Cognitive Functions and Activity of Daily Living among Post- Stroke Patients. Althea Medical Journal, 3(3), 329333

Rachmawati, F., Utomo,W., Nauli, F.A. 2013. Gambaran Status Fungsional Pasien Stroke Saat Masuk Ruang Rawat Inap Rsud Arifin Achmad Pekanbaru.[Skripsi]. PSIK Universitas Riau.
Rudd, N.A., dan Lennon S.J. (2000). Body Image and Appearance : Management Behaviors in College Woman. Clothing and Textiles Research Journals, 18, 52 - 162.

Smeltzer \& Bare. 2002. Keperawatan Medikal Bedah. Jakarta. EGC.

Wirawan, R. P. (2009). Rehabilitasi Stroke pada pelayanan kesehatan primer. Majalah Kedokteran Indonesia, 59(2), 61-71.

World Health Organization, 2010, The Atlas of Heart Disease and Stroke.

Yenni. (2011). Hubungan dukungan keluarga dan karakteristik lansia dengan kejadian stroke pada lansia hipertensi di wilayah kerja puskesmas perkotaan BukitTinggi. 